Additional Perspectives articles for Influenza: The Cutting Edge book collection are available at http://perspectivesinmedicine.cshlp.org/cgi/collection/influenza_the_cutting_edge.

\title{
Human Susceptibility to Influenza Infection and Severe Disease
}

\author{
Robert C. Mettelman and Paul G. Thomas \\ Department of Immunology, St. Jude Children's Research Hospital, Memphis, Tennessee 38105, USA \\ Correspondence: Paul.Thomas@stjude.org
}

Influenza viruses are a persistent threat to global human health. Increased susceptibility to infection and the risk factors associated with progression to severe influenza-related disease are determined by a multitude of viral, host, and environmental conditions. Decades of epidemiologic research have broadly defined high-risk groups, while new genomic association studies have identified specific host factors impacting an individual's response to influenza. Here, we review and highlight both human susceptibility to influenza infection and the conditions that lead to severe influenza disease.

nfluenza viruses are segmented, negative-sense RNA viruses that readily infect the respiratory tracts of humans and animals (Bouvier and Palese 2008). In humans, seasonal infections arising from influenza A and B viruses are widespread and cause upward of 650,000 annual deaths, whereas pandemic events occur sporadically with wide-ranging impact (Iuliano et al. 2018). Among healthy adults, infections by influenza A viruses (IAVs) are acute, self-limiting, and commonly resolved without the onset of serious illness. However, numerous viral and host factors can significantly impact disease severity leading to numerous short- and long-term complications and death (Beigel 2008). For example, during the 1918-1919 Spanish flu, the most severe influenza outbreak ever recorded, an estimated $25 \%-30 \%$ of the global population became infected, resulting in a $2.5 \%$ mortality rate or more than 40 million deaths (Taubenberger et al. 2001). Conversely, severe influenza disease asso- ciated with seasonal influenza arises in $<1 \%$ of cases (Taubenberger and Morens 2006; CDC 2018). This discrepancy leads to many interesting and important questions related to human susceptibility to IAV. What factors increase the risk of influenza infection in otherwise healthy individuals? What are the high-risk groups associated with progression to severe influenza disease? Answering these questions and defining the underlying conditions that cause susceptibility to infection and significant disease variability between individuals have been an ongoing research agenda for the past century. Here, we review the dual aspects of human susceptibility to influenza considering both the conditions that lead to enhanced infection of healthy adults and the risk factors associated with severe influenza disease. Having a clear idea of vulnerable populations during a virus outbreak and the ability to predict the severity of infection early on are critical measures necessary for mitigating disease

Editors: Gabriele Neumann and Yoshihiro Kawaoka

Additional Perspectives on Influenza: The Cutting Edge available at www.perspectivesinmedicine.org

Copyright (C) 2021 Cold Spring Harbor Laboratory Press; all rights reserved; doi: 10.1101/cshperspect.a038711

Cite this article as Cold Spring Harb Perspect Med 2021;11:a038711 
R.C. Mettelman and P.G. Thomas

and transmission as well as modeling the impact of influenza across the globe.

\section{SUSCEPTIBILITY TO INFLUENZA INFECTION IN HEALTHY ADULTS}

\section{Initial Exposure and Virus-Intrinsic Considerations}

IAVs are transmitted within large, mucus-laden droplets or smaller particles, called "aerosols," that are expelled from the airways of an infected human or animal during normal respiration as well as fits of coughing or sneezing (Tellier 2006; Yan et al. 2018). These infectious materials must come into contact with the mucous membrane of a susceptible human to establish infection. The nature of disease arising from this infection is dependent on the size of the virus inoculum, the site of infection, strain-associated virulence, and other virus-intrinsic factors concomitant with the transmitting IAV.

Factors affecting initial virus exposure are often the first considerations made when determining susceptibility among healthy individuals. Aerosol particle size, virus inoculum concentration, the relative distance an expelled aerosol can travel, and the environmental stability of infectious droplets are all affected by seasonal fluctuations in temperature and humidity. Indeed, all of these IAV exposure risks increase during the cooler, drier months in temperate climates and broadly result in higher probability of infection (Shaman and Kohn 2009; McDevitt et al. 2010; Shaman et al. 2010; Deyle et al. 2016; Marr et al. 2019). In contrast, tropical and subtropical regions experience higher rates of influenza infection during seasonal periods of humid-rainy conditions, which are associated with sustained high levels of specific humidity and temperature (Moura et al. 2009; Mahamat et al. 2013; Tamerius et al. 2013; Chadsuthi et al. 2015). Although the individual climate factors that contribute to increased influenza cases are complex and vary by region, it is important to note that under either environmental condition, cold-dry or humid-rainy, the proportion of susceptible individuals is increased during these aptly termed "flu seasons."
Subtle genetic changes across IAV populations, which can accumulate at the individual infection level or regionally during an outbreak, can also impact human susceptibility. Influenza viruses have a high degree of strain-to-stain variation stemming from potential reassortment between the segmented RNA genomes, and the lack of proofreading mechanisms associated with the viral RNA-dependent RNA polymerase (Burnet and Lind 1951; Steinhauer et al. 1992; Downie 2004). During the course of infection, influenza viruses replicate as genetically diverse "quasispecies," which arise from point mutations that sample the functional genetic range of each viral component (Domingo et al. 1998). Subtle variation in hemagglutinin (HA) $\mathrm{pH}$ sensitivity, thermal stability of the polymerase, and relative activity of IAV virulence factors such as NS1 have all been shown to affect IAV virulence and transmission (Mehle and Doudna 2009; Clark et al. 2017; Russell et al. 2018). Therefore, exposure to a larger virus inoculum allows for a more diverse sampling of the influenza quasispecies, which may contain viruses with infection- or susceptibility-enhancing mutations.

Virus-intrinsic changes in influenza antigenic novelty also impact susceptibility to infection in healthy individuals, through both stochastic mutation of viral proteins and selective pressures imposed by host immunity. Point mutations often arise in the HA and neuraminidase (NA), two major influenza surface antigens (Fitch et al. 1991; Koelle et al. 2006). Termed "antigenic drift," these mutations can alter the surface landscape of invading viruses such that they are no longer recognized by preexisting immunity (Both et al. 1983; Kim et al. 2018). Large-scale changes in HA and NA pairings can also affect human susceptibility. Antigenic shift results from HA and NA gene segment reassortment events, which can occur during co-infection of dually infected cells by IAVs encoding different HA or NA subtypes (Burnet and Lind 1951; Webster et al. 1982; Downie 2004). Antigenic shift events are largely responsible for zoonotic emergence of pandemic IAV strains, such as the 2009 A/H1N1 pandemic virus outbreak that percolated throughout the global population in 2009 (Webby and 
Webster 2001; CDC 2009a,b; Kim et al. 2018). Increased susceptibility to these viruses is largely due to population-wide immune naïveté to a particular HA, but can also be attributed to more specific receptor engagement or strainspecific virulence. Receptor-binding specificity of influenza HA proteins has also been shown to impact human susceptibility, virus pathogenicity, and transmissibility of IAV (Imai and Kawaoka 2012; Neumann and Kawaoka 2015). The natural ligand for influenza HA is sialic acids that decorate the terminal ends of host surface proteins (Couceiro et al. 1993; Bouvier and Palese 2008). The susceptibility of an individual cell to an influenza virion is determined by the engagement of HA with sialic acid with $\alpha 2,3$ - or $\alpha 2,6$-linkage to the penultimate galactose, as well as the $\mathrm{pH}$ of the surrounding lumen (Skehel and Wiley 2000; Stevens et al. 2006). Within the human respiratory tract, $\alpha 2,6$-linked sialic acids are found in the upper airways, whereas $\alpha 2,3$ linked sialic acids are detected on some cells of the lower respiratory tract, including the lung. Influenza strains that bind $\alpha 2,6$-linked sialic acids, such as pandemic and seasonal H1N1 viruses, replicate in the upper airways, resulting in mild disease and high rates of transmission (Maines et al. 2009). Conversely, influenza virus strains that bind $\alpha 2,3$-linked sialic acids in the lung tend to cause more severe disease, at the cost of transmission efficiency (Murphy et al. 1982; Beare and Webster 1991; Matrosovich et al. 2004). The highly pathogenic avian influenza strains $\mathrm{A} / \mathrm{H} 5 \mathrm{~N} 1$ and $\mathrm{A} / \mathrm{H} 7 \mathrm{~N} 9$, which cause severe pneumonia, are prime examples of this trade-off between virulence and transmission (Zitzow et al. 2002; Nicholls et al. 2007; Gambotto et al. 2008; Ramos et al. 2013). Thus, human susceptibility to infection or severe disease can be directly affected by initial virus exposure, strainto-strain variations in IAV genetics and pathogenicity, and the site of influenza replication.

\section{Vaccine History and Preexisting Immunity}

Seasonal vaccinations aimed at priming the adaptive immune response against three to four circulating strains of influenza are the preferred approach to reducing individual suscep- tibility and local transmission as well as limiting severe influenza disease (Rajão and Pérez 2018). The adaptive immune response is divided into a humoral component, which can be highly strain-specific, and a cellular component, which has greater inherent cross-reactivity due to targeting linear epitopes in relatively conserved viral proteins. Both arms protect against subsequent exposures to homologous viruses (Boon et al. 2004). In a similar way to vaccination, natural infection also confers protection and increases the number of IAV antigenic variants an individual may respond to. Humoral and cell-mediated immune memory responses are generated against diverse IAV strains during an active infection and, through memory recall of particular antigens, increase the barrier to disease during a secondary exposure through the activity of antibodies and antigen-specific $\mathrm{T}$ cells (Grant et al. 2016; Chen et al. 2018). Amazingly, older individuals, normally a highly susceptible group, experienced lower rates of IAV infection during the $2009 \mathrm{~A} / \mathrm{H} 1 \mathrm{~N} 1$ pandemic likely because of prior exposure to A/ H1N1 antigens in 1918-1919 and the production of cross-neutralizing anti-HA antibodies (Krause et al. 2010). This observation highlights the "critical" importance of preexisting immunity in determining susceptibility to infection. Childhood is a particularly crucial time in developing immunity to influenza. Several lines of inquiry suggest that our first exposure to IAV antigen, by natural infection or vaccination, determines the specificity and scale of lifelong antiviral immunity. Evidence for this "original antigenic sin" indicates that immunologic imprinting may bias humoral and cellular responses toward strains encountered early in life, thereby limiting efficacy against infection by heterotypic influenza strains encountered later (Davenport et al. 1953, 1955; Francis 1960). This may be a major contributing factor to the observed decline in efficacy of seasonal IAV vaccination, which was reported to be as low as 50\% against $\mathrm{A} / \mathrm{H} 3 \mathrm{~N} 2$ in recent seasons (Ohmit et al. 2014; McLean et al. 2015; Zimmerman et al. 2016; Flannery et al. 2017, 2018; Jackson et al. 2017). Thus, it is becoming increasingly important that a high percentage of people receive the 
annual influenza vaccine to establish effective herd immunity and reduce the pool of susceptible individuals.

\section{Additional Considerations}

Many other factors contribute to increased risk of IAV infection among healthy adults. Occupational hazards are a good example. Health-care personnel are at increased risk of exposure to IAV as was shown during the $2009 \mathrm{~A} / \mathrm{H} 1 \mathrm{~N} 1$ pandemic (Lietz et al. 2016). Individuals who work in close contact with animals, such as birds and swine, may also have an increased risk of zoonotic transmission (Harris et al. 2017; Root et al. 2017). Although rare, the zoonotic emergence of novel IAV strains has resulted in some of the most widespread influenza virus outbreaks in history (Webster and Laver 1972; Taubenberger and Kash 2010). Age is another hallmark risk factor. Children younger than 5 are at increased risk of infection, likely because of immature immune development, discussed in detail below. As a result, healthy adults that work with children, such as day-care providers or early educators, or those who have young children at home are $>1.5$ times more likely to come into contact with influenza viruses (Root et al. 2017; Huang et al. 2019). A final consideration for increased susceptibility to IAV infection is population density. Because of the nature of aerosol and direct-contact transmission of IAV, individuals who live or work in areas with a high population density, such as large cities, are much more likely to come into contact with the virus (Loth et al. 2011; Gilbert and Pfeiffer 2012). Outbreaks within localized, dense populations such as summer camps were also prevalent during the 2009 A/H1N1 outbreak (Doyle and Hopkins 2011).

Together, these viral, host, and environmental factors, summarized in Figure 1A, affect the susceptibility of otherwise healthy individuals to IAV infection irrespective of disease severity. Following the successful establishment of IAV infection within a host, a multitude of conditions define an individual's susceptibility to severe influenza-associated disease and are discussed in detail in the following section.

\section{SUSCEPTIBILITY TO SEVERE INFLUENZA DISEASE}

Currently, the Centers for Disease Control and Prevention (CDC) prioritizes several high-risk groups for influenza vaccination including individuals older than 65 , young children, pregnant women, patients with underlying illnesses such as asthma, diabetes, and heart disease, HIV/ AIDS and cancer patients with immunocompromised status, and children with neurological conditions (Grohskopf et al. 2019). These demographic groups are traditionally the most susceptible to severe influenza diseases including acute respiratory illness (ARI) with fever, termed influenza-like illness (ILI), and ARI that requires hospitalization, often termed severe acute respiratory illness (SARI) (WHO 2013). In the wake of the $2009 \mathrm{~A} / \mathrm{H} 1 \mathrm{~N} 1$ pandemic, growing numbers of large-scale genome analyses have uncovered dozens of gene variants and host factors that may predispose individuals to poor outcomes. In addition, numerous cohort studies have also helped define correlates of protection against influenza disease and predict correlates of severity following infection. A sampling of these studies will be discussed within the context of human susceptibility to severe influenza disease and is summarized in Figure 1B.

\section{Host Demographics}

Age

Advanced age is one of the most prominent risk factors for developing severe influenza disease. Individuals older than 65 account for $\sim 90 \%$ of influenza-related deaths and are four times more likely to suffer disease complications (Thompson et al. 2003; Mertz et al. 2013). Much of this risk is due to progressive immune deterioration, termed "immune senescence," experienced during aging, which results in increased susceptibility to viral and bacterial infections and muted vaccine responses (McElhaney and Effros 2009). Immune senescence affects both innate and adaptive responses (Shaw et al. 2013; Carr et al. 2016). Critical innate antiviral responses such as type I interferon signaling are 
Host Susceptibility to Influenza in Humans

A

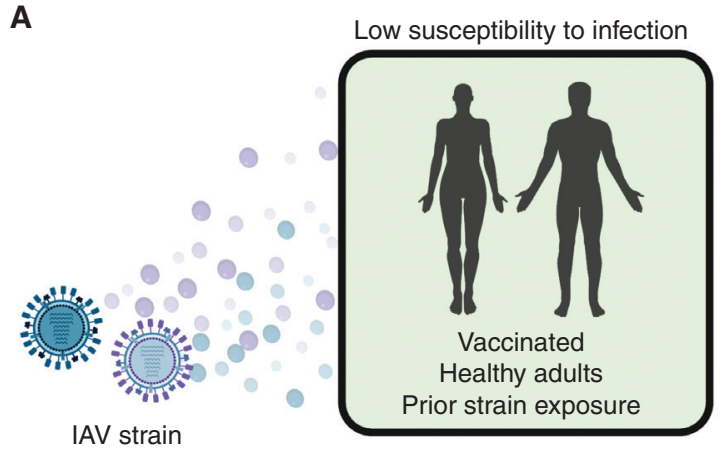

Inoculum size

Antigen uniqueness

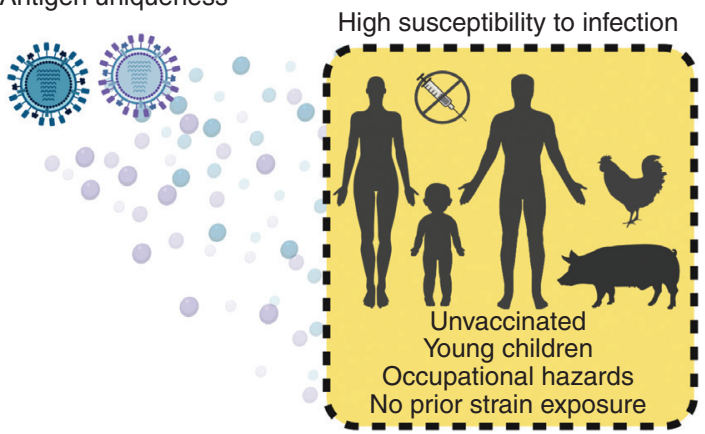

B

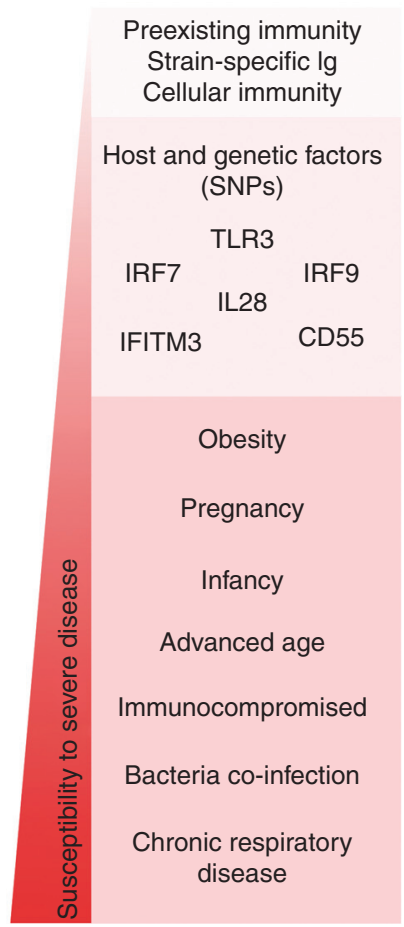

Figure 1. Factors impacting human susceptibility to influenza infection and disease severity. (A) Viral, host, and environmental conditions that affect susceptibility to influenza A infection. (B) Several demographic, immune, and genetic factors on a relative scale of associated susceptibility to influenza disease severity.

subdued and do not readily establish the antiviral state required to effectively promote virus clearance (Canaday et al. 2010; Sridharan et al. 2011; Prakash et al. 2013; Pillai et al. 2016). Further, pro-inflammatory cytokine production becomes dysregulated. In some cases, individuals develop a senescence-associated secretory phenotype, often referred to as "inflammaging," which causes increased pro-inflammatory cytokine production and low-grade chronic inflammation (Franceschi et al. 2000; Brüünsgaard and Pedersen 2003; McElhaney and Effros 2009). During influenza infection, this inappropriate inflammatory response leads to excessive immune pathology, damage to lung tissue, persistence of symptoms, and an increased probability of progressing to acute respiratory distress syndrome (ARDS) (Ginaldi et al. 2001; Toapanta and Ross 2009; Cavanagh et al. 2012; Le Saux et al. 2012; Solana et al. 2012). Immune senescence also affects the adaptive immune response in older individuals. Degradation of T-cell responses is attributed to "thymic involution," or the gradual reduction in naive T-cell output from the thymus and the amount of time newly minted $\mathrm{T}$ cells spend in peripheral circulation (Franceschi et al. 2000; Meyer 2001; Palmer 2013). Thymic involution has profound effects on the development of $\mathrm{CD}^{+}{ }^{+} \mathrm{T}$ helper cell responses following vaccination as well as cytotoxic $\mathrm{CD}^{+} \mathrm{T}$-cell response to infection by novel influenza strains (Meyer 2001). The total diversity of the influenza-specific T-cell receptor (TCR) narrows during aging, further decreasing the ability to recognize and respond to diverse IAV antigens (Gil et al. 2015). Importantly, the potential for $\mathrm{T}$ - and $\mathrm{B}$-cell clonal expansion in response to novel antigens is also reduced in aging individuals. One contributor to this effect may be the large clone sizes generated by responses to persistent viral infections, such as cytomegalovirus (CMV) (Khan et al. 2002). 
Chronic insults with CMV further impair aging immune function and elicit robust $\mathrm{CD} 8^{+} \mathrm{T}$-cell clonal expansion, thus reducing the ability to respond to new infections (Lindau et al. 2019). Interestingly, the opposite is true in young individuals, further highlighting the age-dependent effects of immune development on IAV responses (Furman et al. 2015). Finally, the number of $\mathrm{B}$ cells, responsible for humoral responses, also decreases with age as does the efficacy of circulating antibodies against specific pathogens (Ferguson et al. 1995; Frasca et al. 2005). Taken together, the effects of advanced age significantly impact IAV disease susceptibility by increasing the potential for immune pathology, limiting vaccine efficacy, and curtailing memory responses to newly encountered influenza strains.

Infants are also at high risk of developing severe influenza disease. Compared with healthy adults, children younger than 2 yr shoulder higher rates of hospitalization, severe complications, and mortality following IAV infection (Munoz 2003; Bhat et al. 2005; Louie et al. 2010). Indeed, pediatric mortality rates were 10 times higher during the $2009 \mathrm{~A} / \mathrm{H} 1 \mathrm{~N} 1$ pandemic than for seasonal influenza in the preceding years (Libster et al. 2010). In a large cohort study of more than 900 unvaccinated individuals in New Zealand, children aged 0-4 yr experienced the highest attack rate for ILI at 14\% (Huang et al. 2019). This increased susceptibility is due in large part to the functional immaturity of the immune system and a failure to recognize influenza antigens. Further age-dependent differences may also be attributed to the exaggerated type 2 immune responses characteristic of the infant immune system, which favor tissue repair over $\mathrm{CD} 8^{+} \mathrm{T}$-cell responses leading to ineffective virus clearance (Garcia et al. 2000; Adkins et al. 2004; Dowling and Levy 2014; de Kleer et al. 2016).

\section{Immunocompromised Status}

Many factors other than age can affect the functionality of the immune system and predispose individuals to serious influenza-related complications. These include both chronic (HIV/ AIDS, organ transplant, and hemodialysis) and transient (stem cell transplant, cancers, and cor- ticosteroid use) immunosuppressive conditions (Kunisaki and Janoff 2009). For example, mortality rates among people in the United States living with HIV/AIDS in the pre-HAART era were 150-208 times higher than the general population and fourfold greater among the elderly (Cohen et al. 2012). Following the introduction of HAART, influenza-related mortality rates dropped fourfold in adults with AIDS (Cohen et al. 2012), although the effects of AIDS-related comorbidities underscore concerns of enhanced virus shedding and disease severity (Sheth et al. 2011). Patients with certain types of cancers, including lymphoma and leukemia, or patients receiving treatment for cancer including chemotherapy and bone marrow transplantation are at increased risk for SARI (Kunisaki and Janoff 2009). Much of this disease susceptibility stems from suppressed, or in some cases ablated, adaptive immune responses and an inability to effectively clear the influenza infection.

\section{Sex and Pregnancy}

Although the underlying mechanisms are not fully understood, it is widely appreciated that immunity differs between the sexes, with females exhibiting more robust responses to infection and vaccination compared with men (Klein and Flanagan 2016; Gubbels Bupp et al. 2018). Several groups have investigated how these differences in sex impact influenza disease outcomes and vaccine efficacy. When comparing immune responses in men and women given a trivalent inactivated influenza vaccine (TIV), one group found that differential expression of sex hormones correlated with differences in immune development (Furman et al. 2014). As expected, women had increased levels of inflammatory cytokines and higher antibody titers to TIV than men. Further, increased levels of endogenous testosterone were negatively correlated with IAV vaccine efficacy. However, possibly because of this increased pro-inflammatory response to IAV, survey and epidemiologic evidence obtained from seasonal and pandemic IAV outbreaks suggest that females of reproductive age experience higher overall rates of severe 
IAV disease during outbreaks of $\mathrm{A} / \mathrm{H} 1 \mathrm{~N} 1$, $\mathrm{A} / \mathrm{H} 5 \mathrm{~N} 1$, and A/H7N9 (WHO 2010; Robinson et al. 2011; Klein et al. 2012; Hoffmann et al. 2015). Interestingly, when age and sex are considered as covariates, IAV incidence changes as a function of age. From birth through age 15, males are disproportionally infected, whereas IAV incidence increases in females after puberty (Hackett et al. 2009; Eshima et al. 2011; Rhim et al. 2012; Krementsov et al. 2017). As sex hormones steadily decrease following puberty, it is possible that a degree of age-related susceptibility can be attributed to decreased estrogen and testosterone levels, resulting in increased inflammation.

Pregnancy is the most prominent sex-related risk of developing severe IAV disease (Gabriel and Arck 2014). In fact, during the 2009 A/ H1N1 pandemic, pregnant women were seven times more likely to experience severe disease than nonpregnant women, and two times more likely to succumb to complications related to infection (Siston et al. 2010). At present, pregnant women comprise $5 \%$ of total IAV-related deaths in the United States (Siston et al. 2010). The exact factors that underpin the increased susceptibility of pregnant women to IAV-related diseases remain unknown; however, it is likely that the dysregulated inflammation and reduced innate responses observed during pregnancy play major roles. It should also be noted that fever associated with influenza infection during pregnancy is a significant risk to the developing child, with complications associated with defects in the neural tube and other adverse events.

\section{Obesity}

Obesity was first recognized as a risk factor for IAV-related death during the 2009 A/H1N1 pandemic (Vaillant et al. 2009; Louie et al. 2009 , 2011) and subsequently during A/H7N9 outbreaks (Liu et al. 2014). Obese individuals experienced significantly higher rates of influenza-related hospitalizations and more often required ventilator support and intensive care (Mertz et al. 2014). Mounting evidence suggests that obesity affects the efficacy of adaptive immune generation in response to influenza vacci- nation or infection. Indeed, $\mathrm{T}$ cells obtained from obese subjects expressed lower levels of surface activation markers and effector molecules including type II interferon and granzyme $\mathrm{B}$ and were less activated following stimulation with IAV vaccine strains (Sheridan et al. 2012; Paich et al. 2013; Painter et al. 2015; Maier et al. 2018; Yan et al. 2018). Body mass index (BMI) is correlated with waning antibody titers in response to IAV vaccination after $12 \mathrm{mo}$, suggesting an inability to properly establish substantial immune memory (Sheridan et al. 2012). These findings were further confirmed in a study, which found that vaccinated obese individuals were two times more likely to suffer influenzarelated illness than vaccinated healthy-weight counterparts (Neidich et al. 2017). Finally, BMI has been found to correlate with increased duration of virus shedding even without clinical disease (Maier et al. 2018). Thus, increased BMI can be considered a significant risk factor for susceptibility to severe influenza disease and may increase rates of transmission. The connection between obesity and severe influenzarelated illness, however, is complex. Although identified as an independent risk factor, obesity is often associated with other comorbidities including diabetes, cardiovascular, and pulmonary diseases, which also independently correlate with severe influenza disease (Koenig 2001; Louie et al. 2009; Poirier et al. 2009).

\section{Comorbidities}

Underlying medical conditions play a large role in susceptibility of individuals to severe influenza disease. During the 2009 A/H1N1 pandemic, individuals with diabetes (and no other underlying condition) suffered more severe influenza disease and experienced triple the rate of hospitalizations compared with the general population (Allard et al. 2010; Wilking et al. 2010). Diabetic fluctuations in blood glucose levels, called "glycemic variability," have broad-ranging effects on immune function and can be further perturbed by influenza infection resulting in enhanced disease (Hulme et al. 2017). Other preexisting medical conditions that impair lung and airway function result in significant risk for 
developing SARI. Chronic respiratory diseases such as chronic obstructive pulmonary disease (COPD) and pulmonary fibrosis are linked to an inability to effectively clear influenza from the airways (Glezen et al. 2000; Papi et al. 2006). Asthma is of particular concern in children, who are already at increased risk of influenza disease (Libster et al. 2010; O’Riordan et al. 2010; Plessa et al. 2010).

\section{Microbiome Disruption and Bacterial Coinfection}

The resident bacterial microbiome outnumbers cells in the human body 10 to 1 and has widereaching impacts on immune development, metabolism, allergy, and regulation of inflammation. It is no surprise then that perturbations in the healthy microbiome can impact responses to respiratory infections such as influenza. A recent study integrated multi-omics data collected from antibiotic-treated patients given influenza vaccination to determine how disruption of the gut microbiota impacted vaccine responses (Hagan et al. 2019). Amongst subjects with little preexisting immunity, antibiotic treatment diminished antigen-specific IgG and IgA responses. Loss of the gastrointestinal microbiota was also linked to an increased inflammatory profile, reminiscent of elderly individuals, suggesting that dysbiosis may be a risk factor for both susceptibility to infection as well as severe disease. The microbial composition within the human respiratory tract is also impacted by influenza infection in both children and adults. Indeed, administration of the live attenuated influenza vaccine (LAIV) has been shown to increase bacterial colonization density in children (Thors et al. 2016) and perturb the nasopharyngeal microbiome in adults (de Steenhuijsen Piters et al. 2019). In the latter, the disrupted microbiome and inflammatory profile associated with LAIV allowed more significant colonization by pneumococcal bacteria and thus may increase the potential to transmit these harmful bacteria to susceptible individuals (de Steenhuijsen Piters et al. 2019).

Secondary bacterial infections, particularly those that lead to pneumonia, are common fol- lowing influenza. These superinfections are strongly associated with enhanced mortality rates observed during several early influenza pandemics, in particular the 1918-1919 Spanish flu during which a majority of deaths were attributed to bacterial pneumonia (Morens et al. 2008). Although these bacterial infections are opportunistic and piggyback virus-mediated immune depletion, enhanced IAV replication is also observed, albeit by an as-yet unknown mechanism (McCullers 2014). The relationship between virus infection, bacterial colonization, and enhanced disease is broadly understood: (1) Secondary bacterial infections are established following depletion of alveolar macrophages and suppression of innate immunity by primary IAV infection; (2) factors produced by the bacteria maintain immune suppression and impair bacterial clearance; and (3) a bump in IAV titers paired with unchecked bacterial replication results in persistent pneumonia and severe outcomes (McCullers 2014). Most secondary pneumonia following IAV infection is attributed to one of three common upper-respiratory bacteria strains, Staphylococcus aureus, Streptococcus pneumoniae, and Haemophilus influenzae (Smith and McCullers 2014; Mulcahy and McLoughlin 2016; Morris et al. 2017). Several groups have suggested that bacterial proteases produced by these strains may enhance or facilitate influenza virus infection through cleavage of the viral HA, although no additional links have been made (Tashiro et al. 1987). Rather than any individual factor, it is likely that synergistic disruption of innate immunity and dysregulated inflammation by superinfecting IAV and bacteria lead to significantly impaired lung function and severe, often fatal, pneumonia.

\section{Host Factors and Gene Variants}

The connection between host genetics and susceptibility to IAV disease is a long-standing idea that was first suggested in the earliest human genetic association studies performed following the $1957 \mathrm{~A} / \mathrm{H} 2 \mathrm{~N} 2$ pandemic (Potter and Schild 1967; Watkin et al. 1975). Decades after these seminal studies, new investigations of largescale human cohorts have bolstered the idea 
that certain individuals have genetic predisposition to IAV disease. Preexisting immunity has largely masked the contribution of host genetics to IAV susceptibility in adults, thus many of these associations were first made in naive children following the A/H1N1 pandemic in 2009. Although an incomplete list, variations in at least 25 different host genes have been associated with poor outcomes after IAV infection, and have been extensively reviewed (Horby et al. 2013; Ciancanelli et al. 2016; Clohisey and Baillie 2019; Gounder and Boon 2019). Many of these studies report data based on single nucleotide polymorphisms (SNPs) - positional mutations that may vary between individuals and across populations. Pairing disease outcome observations with genetic SNP data obtained in large cohort genome-wide association studies (GWAS) can help identify genes critical to protection from influenza, but also factors that may predispose an individual to severe disease. Continuing to identify these genetic factors and at risk individuals may further influence vaccine priority during future outbreaks. Below, we consider several of these factors, which impact innate signaling and antiviral response following influenza infection.

\section{Innate Signaling}

Sensing the presence of virus replication and modulating an appropriate response are the two primary tenants of the innate immune system. With respect to viral infection, these responses center around numerous patternrecognition receptors (PRR), which recognize specific molecular signatures present on viral components and trigger the production of the antiviral signaling molecule interferon (IFN). Toll-like receptor (TLR) 3 is one such PRR and is activated by virus-produced doublestrand RNA (dsRNA) species in the cell cytoplasm (Iwasaki and Pillai 2014). Two studies have identified SNPs in the human TLR3 gene that correspond to increased IAV disease severity. The first study, performed in Italy in the wake of the $2009 \mathrm{~A} / \mathrm{H} 1 \mathrm{~N} 1$ pandemic, involved 272 children admitted to the emergency room for influenza-related SARI and 164 healthy controls (Esposito et al. 2012). From this cohort, researchers identified the TLR3 polymorphism rs5743313-CT, which was associated with increased risk of pneumonia in children infected with 2009 A/H1N1 pandemic virus. Importantly, the group found that viral loads were comparable across groups, suggesting that polymorphisms in TLR3 do not necessarily impact "occurrence" of infection, but rather predisposed these children to more severe disease. A second study, conducted on a large cohort of 275 adults with avian A/H7N9 or 2009 $\mathrm{A} / \mathrm{H} 1 \mathrm{~N} 1$ pandemic virus infections in China, examined associations between SNPs of several innate immune signaling components, including IFITM3, CD55, and the previously identified TLR3 SNP rs5743313 (Chan et al. 2017). In this cohort, the TLR3-C allele frequency was comparable to the 1000 Genomes Han Chinese data, yet it was overrepresented among fatal cases.

Downstream from PRR sensing, signal cascades converge to promote expression of type I $(\alpha \beta)$ and type III $(\lambda)$ IFNs - the major antiviral signaling molecules that establish the so-called "antiviral state." Among these signaling components are two key IFN transcription factors, interferon regulatory factor (IRF) 7 and 9. The case study of a patient with an autosomal-recessive, complete IRF7 deficiency was first reported in 2015 and represents the first genetic etiology of a single-gene inborn error conferring susceptibility to IAV disease (Ciancanelli et al. 2015). The patient, a 2.5-yr-old experiencing severe ARDS, inherited two independent loss-offunction alleles from parents who were both heterozygous carriers. Evaluation of purified plasmacytoid dendritic cells and peripheral blood mononuclear cells (PBMCs) obtained from the patient showed significantly lower expression of type I and III IFN following infection by $\mathrm{A} / \mathrm{H} 1 \mathrm{~N} 1$, providing functional support of the disease severity observations. Nonfunctional mutation in IRF9 has also been identified as a risk factor for severe pulmonary influenza (Hernandez et al. 2018). In a 2018 study, investigators reported the case of a 2-yr-old with life-threatening influenza disease arising from loss-of-function mutation of IRF9. The particular IRF9 SNP identified in the study leads to 
expression of a truncated protein with only partial activity. As a result, the patient's cells were unable to activate IFN-stimulated gene factor 3 (ISGF3) in response to type I IFN and did not control replication of three respiratory viruses including IAV, parainfluenza, and respiratory syncytial virus in vitro. Interestingly, the child was able to control other respiratory infections other than IAV in vivo, suggesting a particularly important role for IRF9 in controlling influenza. Last, several SNPs have also been identified in the type III IFN (IL28) gene, with divergent effects depending on the exact polymorphism. One IL28B SNP (rs8099917-GG/TG) was associated with increased seroconversion and improved responses to IAV vaccination, whereas another (s8099917-TT) correlated with increased risk of IAV-related illness (Rogo et al. 2016). Thus, defects in the ability to sense virus replication and signal for IFN transcription as well as the function of IFN can all significantly impact individual susceptibility to IAV disease.

\section{Antiviral Response}

The end result of type I and III IFN signaling is the expression of hundreds of interferon-stimulated genes (ISGs) - a constellation of antiviral effector proteins, pro-inflammatory molecules, and chemotactic factors that promote virus clearance and development of adaptive immunity. One such ISG, IFN-induced transmembrane protein 3 (IFITM3), acts as a potent viral restriction factor by blocking virus-host membrane fusion events at the endosomal surface thereby preventing delivery of viral RNA into the cytoplasm (Feeley et al. 2011; Amini-BavilOlyaee et al. 2013; Desai et al. 2014). Several groups have reported polymorphisms in IFITM3 that correlate with severe outcomes following influenza infection. The IFITM3 SNP rs12252-C allele was first identified following the $2009 \mathrm{~A} / \mathrm{H} 1 \mathrm{~N} 1$ pandemic, in which it was found to associate with fatal IAV disease, especially amongst Han Chinese who have a higher frequency of the rs12252-C allele compared with Caucasian populations (Everitt et al. 2012; Zhang et al. 2013). The risk of progressing to severe IAV disease was further confirmed amongst Chinese patients who became infected with emergent A/H7N9 virus (Zhang et al. 2013). The effect of the rs12252-C allele on the expression or function of IFITM3 remains unknown. Although initially thought to affect splicing, thereby producing a truncated protein, a follow-up study found that full-length IFITM3 mRNAs were present in all rs12252 genotypes, further complicating the story (Makvandi-Nejad et al. 2018). Arising from population-level analysis of three independent influenza-infected cohorts, a second IFITM3 polymorphism (rs34481144-A) was identified in largely nonChinese populations (Allen et al. 2017). This polymorphism was associated with a 2.6-fold increase in risk of developing severe IAV disease. SNP rs34481144 is located within the IFITM3 promoter region ( $5^{\prime}$ UTR) and impacts expression and protein levels of IFITM3, CpG methylation, as well as CTCF binding-a protein involved in chromatin remodeling. As a result, the risk allele negatively impacts transcription of IFITM3 and IFITM3-neighboring genes in response to IAV infection. This was found to be particularly detrimental in $\mathrm{CD}^{+} \mathrm{T}$ cells, with reduced numbers of these critical cytotoxic leukocytes in the airways of patients harboring the risk allele.

The complement system of serum proteins is another important innate immune component, which can play a protective role during IAV infection (O'Brien et al. 2011). Under normal conditions, complement promotes inflammation and can direct opsonization or lysis of virus-infected cells. However, prolonged complement activation can significantly damage host cells and cause systemic tissue destruction during influenza infection because of immune complex formation (Monsalvo et al. 2011). CD55, also termed "decay accelerating factor" (DAF), is a key negative regulator of complement activation that facilitates the removal of C3 and C5 convertases from the plasma (Medof et al. 1984; Kim and Song 2006). Polymorphisms in CD55, particularly rs2564978-T/T, decrease the surface expression of this protein on myeloid cells and are associated with severe disease among pandemic A/H1N1-infected patients (Zhou et al. 2012). These findings were con- 
firmed in a second study of 275 adults infected with avian A/H7N9 or $2009 \mathrm{~A} / \mathrm{H} 1 \mathrm{~N} 1$ pandemic viruses in China. As discussed above, researchers examined associations between SNPs in several genes including TLR3, IFITM3, and CD55 and noted significant associations between the rs2564978-T/T risk allele and severe pneumonia and death (Chan et al. 2017).

It should also be noted that genetic variation can also impact adaptive immune responses to influenza. Indeed, a 2002 study investigated the relationship between human lymphocyte antigen (HLA) type and control of influenza infections (Boon et al. 2002). Researchers found that PBMCs obtained from individuals with HLA$\mathrm{A} 2+$ had the highest rates cytotoxic T-lymphocyte (CTL) activity in response to influenza, compared with other donors with different HLA-A or HLA-B alleles. These findings indicate individual genetic variations in adaptive immunity impact the recognition of specific IAV epitopes as well as determine the magnitude of virus-specific CTL responses.

\section{Immune Correlates of Protection and Severity}

Apart from individual host and genetic factors, which may impact disease outcome following influenza infection, high-resolution immune profiling can be used to determine whether the outcome of infection is protection or disease. These measurable signs of immune protection are collectively referred to as "correlates of protection" and can differ significantly between pathogens. In some cases, it is possible to determine "correlates of severity" of a particular disease. These immune responses can predict (or themselves determine) the "severity" of disease. In influenza research, understanding both the correlates of protection and severity is critically important in vaccine design as well as for early diagnosis of individuals with predisposition to severe IAV disease. As a result, many groups have studied the immune features associated with protection following IAV infection. In one study, researchers tested the immunologic basis of severe influenza at the site of infection and were able to define unique immune profiles predictive of either hospitalization or progres- sion to severe disease (Oshansky et al. 2014). Children with increased levels of IL10, IL6, and MCP3 in plasma were more likely to be hospitalized following IAV infection, whereas those with increased MCP3 and IFN $\alpha 2$ in nasal lavage paired with elevated serum IL10, were more likely to progress to severe IAV disease. Interestingly, these immune profiles were irrespective of both age and viral load, highlighting that individual-level variation in immune responses can have a significant impact on susceptibility to IAV disease. Another study followed a cohort of 342 healthy individuals over a single $\mathrm{A} / \mathrm{H} 1 \mathrm{~N} 1$ influenza season in the United Kingdom to identify cellular correlates of protection (Sridhar et al. 2013). In this case, researches correlated low IAV symptom scores with increased levels of so-called "late effector" $\mathrm{T}$ cells with a $\mathrm{CD}^{+} / \mathrm{IFN}-\gamma^{+} / \mathrm{CD}^{2} 5 \mathrm{RA}^{+} / \mathrm{IL}^{-}{ }^{-} /$ $\mathrm{CCR}^{-}$profile. These IAV epitope-specific $\mathrm{CD}^{+} \mathrm{T}$ cells homed to the lungs and, in the absence of cross-reactive neutralizing antibodies, correlated with cross protection against symptomatic influenza. Humoral responses specific to the HA and NA are well-known correlates of protection against influenza (McElhaney et al. 2013; Monto et al. 2015; Ng et al. 2019) Interestingly, a follow-up study by the same group determined that humoral immunity was maintained for longer following infection (>15 mo) compared with vaccination, which waned after 3-4 mo (Sridhar et al. 2015). This highlights that both antibody and cellular responses determine the disease outcome of influenza infection and are important, independent factors to consider when determining susceptibility to infection and severe disease. A subsection of a larger cohort study enrolled 54 participants across the peak influenza season in 2013 in New Zealand (Wong et al. 2018). Investigators aimed to identify the immunologic factors underlying patient progression to SARI compared with those who developed nonlife-threatening ILI. Comparable to other cases, dysregulated inflammation played a key role with disease severity. A delay in peripheral immune activation characterized by reduced levels of immuneregulatory cytokines, virus-specific $\mathrm{CD}^{+}$and $\mathrm{CD}^{+} \mathrm{T}$ cells, and certain monocyte populations 
likely lead to prolonged inflammation. This proinflammatory correlate of severity is yet another example of how the landscape of immune response to influenza can determine individual susceptibility to influenza disease.

\section{CONCLUDING REMARKS}

The burden of human infection and disease caused by influenza viruses is a continuing global challenge, which must be met with a combined effort of research, surveillance, and medicine. Numerous factors can lead to susceptibility to infection by healthy adults-many of whom can prevent transmission of the virus by simple vaccination. As research continues, more groups of individuals at high risk of influenza-related disease are being identified. It is imperative that these individuals are prioritized for vaccination and antiviral treatment during pandemic and even seasonal outbreaks.

\section{ACKNOWLEDGMENTS}

We thank Dr. E. Kaitlynn Allen for helpful discussions and review of the manuscript. This work was supported by funding from American Lebanese Syrian Associated Charities (ALSAC) (R.C.M. and P.G.T.), the National Institute of Allergy and Infectious Diseases (NIAID) (1U01AI144616-01) (R.C.M. and P.G.T.), and the St. Jude Center of Excellence for Influenza Research and Surveillance, HHSN2722014000 06C (P.G.T.).

This article has been made freely available online courtesy of TAUNS Laboratories.

\section{REFERENCES}

Adkins B, Leclerc C, Marshall-Clarke S. 2004. Neonatal adaptive immunity comes of age. Nat Rev Immunol 4: 553-564. doi:10.1038/nri1394

Allard R, Leclerc P, Tremblay C, Tannenbaum TN. 2010. Diabetes and the severity of pandemic influenza $A$ (H1N1) infection. Diabetes Care 33: 1491-1493. doi:10 $.2337 / \mathrm{dc} 09-2215$

Allen EK, Randolph AG, Bhangale T, Dogra P, Ohlson M, Oshansky CM, Zamora AE, Shannon JP, Finkelstein D, Dressen A, et al. 2017. SNP-mediated disruption of CTCF binding at the IFITM3 promoter is associated with risk of severe influenza in humans. Nat Med 23: 975-983. doi:10 $.1038 / \mathrm{nm} .4370$

Amini-Bavil-Olyaee S, Choi YJ, Lee JH, Shi M, Huang IC, Farzan M, Jung JU. 2013. The antiviral effector IFITM3 disrupts intracellular cholesterol homeostasis to block viral entry. Cell Host Microbe 13: 452-464. doi:10.1016/j .chom.2013.03.006

Beare AS, Webster RG. 1991. Replication of avian influenza viruses in humans. Arch Virol 119: 37-42. doi:10.1007/ BF01314321

Beigel JH. 2008. Concise definitive review: influenza. Crit Care Med 36: 2660-2666. doi:10.1097/CCM.0b013e318 $180 \mathrm{~b} 039$

Bhat N, Wright JG, Broder KR, Murray EL, Greenberg ME, Glover MJ, Likos AM, Posey DL, Klimov A, Lindstrom SE, et al. 2005. Influenza-associated deaths among children in the United States, 2003-2004. N Engl J Med 353: 25592567. doi:10.1056/NEJMoa051721

Boon ACM, de Mutsert G, Graus YMF, Fouchier RAM, Sintnicolaas K, Osterhaus ADME, Rimmelzwaan GF. 2002. The magnitude and specificity of influenza A virus-specific cytotoxic $\mathrm{T}$-lymphocyte responses in humans is related to HLA-A and -B phenotype. J Virol 76: 582 590. doi:10.1128/JVI.76.2.582-590.2002

Boon ACM, de Mutsert G, Van Baarle D, Smith DJ, Lapedes AS, Fouchier RAM, Sintnicolaas K, Osterhaus ADME Rimmelzwaan GF. 2004. Recognition of homo- and heterosubtypic variants of influenza A viruses by human $\mathrm{CD}^{+} \mathrm{T}$ lymphocytes. J Immunol 172: 2453-2460. doi:10.4049/jimmunol.172.4.2453

Both GW, Sleigh MJ, Cox NJ, Kendal AP. 1983. Antigenic drift in influenza virus H3 hemagglutinin from 1968 to 1980: multiple evolutionary pathways and sequential amino acid changes at key antigenic sites. J Virol 48: 52-60.

Bouvier NM, Palese P. 2008. The biology of influenza viruses. Vaccine 26: D49-D53. doi:10.1016/j.vaccine.2008.07.039

Brüünsgaard H, Pedersen BK. 2003. Age-related inflammatory cytokines and disease. Immunol Allergy Clin North Am 23: 15-39. doi:10.1016/S0889-8561(02)00056-5

Burnet FM, Lind PE. 1951. A genetic approach to variation in influenza viruses: 3 . Recombination of characters in influenza virus strains used in mixed infections. J Gen Microbiol 5: 59-66. doi:10.1099/00221287-5-1-59

Canaday DH, Amponsah NA, Jones L, Tisch DJ, Hornick TR, Ramachandra L. 2010. Influenza-induced production of interferon- $\alpha$ is defective in geriatric individuals. J Clin Immunol 30: 373-383. doi:10.1007/s10875-010-9374-9

Carr EJ, Dooley J, Garcia-Perez JE, Lagou V, Lee JC, Wouters C, Meyts I, Goris A, Boeckxstaens G, Linterman MA, et al. 2016. The cellular composition of the human immune system is shaped by age and cohabitation. Nat Immunol 17: 461-468. doi:10.1038/ni.3371

Cavanagh MM, Weyand CM, Goronzy JJ. 2012. Chronic inflammation and aging: DNA damage tips the balance. Curr Opin Immunol 24: 488-493. doi:10.1016/j.coi.2012 .04 .003

CDC. 2009a. Swine influenza A (H1N1) infection in two children-Southern California, March-April 2009. Morb Mortal Wkly Rep 58: 400-402. 
CDC. 2009b. Update: influenza activity-United States, April-August 2009. Morb Mortal Wkly Rep 58: 10091012.

CDC. 2018. Estimated influenza illnesses, medical visits, hospitalizations, and deaths in the United States2017-2018 influenza season. Influ 69: 1845-1853. doi:10.1093/cid/ciz075

Chadsuthi S, Iamsirithaworn S, Triampo W, Modchang C. 2015. Modeling seasonal influenza transmission and its association with climate factors in Thailand using timeseries and ARIMAX analyses. Comput Math Methods Med 2015: 436495. doi:10.1155/2015/436495

Chan PKS, Lee N, Cao B, Ke C, Lu H, Hu Y, Tam CHT, Ma RCW, Guan D, Zhu Z, et al. 2017. IFITM3, TLR3, and CD55 gene SNPs and cumulative genetic risks for severe outcomes in Chinese patients with $\mathrm{H} 7 \mathrm{~N} 9 / \mathrm{H} 1 \mathrm{~N} 1_{\mathrm{pdm} 09}$ influenza. J Infect Dis 216: 97-104. doi:10.1093/infdis/ jix 235

Chen X, Liu S, Goraya MU, Maarouf M, Huang S, Chen JL. 2018. Host immune response to influenza $A$ virus infection. Front Immunol 9: 320. doi:10.3389/fimmu.2018 .00320

Ciancanelli MJ, Huang SXL, Luthra P, Garner H, Itan Y, Volpi S, Lafaille FG, Trouillet C, Schmolke M, Albrecht RA, et al. 2015. Life-threatening influenza and impaired interferon amplification in human IRF7 deficiency. Science 348: 448-453. doi:10.1126/science.aaa1578

Ciancanelli MJ, Abel L, Zhang SY, Casanova JL. 2016. Host genetics of severe influenza: from mouse Mx1 to human IRF7. Curr Opin Immunol 38: 109-120. doi:10.1016/j.coi 2015.12.002

Clark AM, Nogales A, Martinez-Sobrido L, Topham DJ, DeDiego ML. 2017. Functional evolution of influenza virus NS1 protein in currently circulating human 2009 pandemic H1N1 viruses. J Virol 91: e00721-17. doi: 10.1128/JVI.00721-17

Clohisey S, Baillie JK. 2019. Host susceptibility to severe influenza A virus infection. Crit Care 23: 303. doi:10 .1186/s13054-019-2566-7

Cohen C, Simonsen L, Sample J, Kang JW, Miller M, Madhi SA, Campsmith M, Viboud C. 2012. Influenza-related mortality among adults aged 25-54 years with AIDS in South Africa and the United States of America. Clin Infect Dis 55: 996-1003. doi:10.1093/cid/cis549

Couceiro JNSS, Paulson JC, Baum LG. 1993. Influenza virus strains selectively recognize sialyloligosaccharides on human respiratory epithelium; the role of the host cell in selection of hemagglutinin receptor specificity. Virus Res 29: 155-165. doi:10.1016/0168-1702(93)90056-S

Davenport FM, Hennessy AV, Francis T Jr. 1953. Epidemiologic and immunologic significance of age distribution of antibody to antigenic variants of influenza virus. J Exp Med 98: 641-656. doi:10.1084/jem.98.6.641

Davenport FM, Hennessy AV, Stuart-Harris CH, Francis T. 1955. Epidemiology of influenza comparative serological observations in England and the United States. Lancet 266: 469-474. doi:10.1016/S0140-6736(55)93328-6

de Kleer IM, Kool M, de Bruijn MJW, Willart M, van Moorleghem J, Schuijs MJ, Plantinga M, Beyaert R, Hams E, Fallon PG, et al. 2016. Perinatal activation of the interleukin-33 pathway promotes type 2 immunity in the developing lung. Immunity 45: 1285-1298. doi:10.1016/ j.immuni.2016.10.031

Desai TM, Marin M, Chin CR, Savidis G, Brass AL, Melikyan GB. 2014. IFITM3 restricts influenza A virus entry by blocking the formation of fusion pores following virusendosome hemifusion. PLoS Pathog 10: e1004048. doi:10 .1371/journal.ppat.1004048

de Steenhuijsen Piters WAA, Jochems SP, Mitsi E, Rylance J, Pojar S, Nikolaou E, German EL, Holloway M, Carniel BF, Chu MLJN, et al. 2019. Interaction between the nasal microbiota and S. pneumoniae in the context of live-attenuated influenza vaccine. Nat Commun 10: 2981. doi:10 .1038/s41467-019-10814-9

Deyle ER, Maher MC, Hernandez RD, Basu S, Sugihara G. 2016. Global environmental drivers of influenza. Proc Natl Acad Sci 113: 13081-13086. doi:10.1073/pnas .1607747113

Domingo E, Baranowski E, Ruiz-Jarabo CM, Martín-Hernández AM, Sáiz JC, Escarmís C. 1998. Quasispecies structure and persistence of RNA viruses. Emerg Infect Dis 4: 521-527. doi:10.3201/eid0404.980402

Dowling DJ, Levy O. 2014. Ontogeny of early life immunity. Trends Immunol 35: 299-310. doi:10.1016/j.it.2014.04 .007

Downie JC. 2004. Reassortment of influenza A virus genes linked to PB1 polymerase gene. Int Congr Ser 1263: 714718. doi:10.1016/j.ics.2004.02.140

Doyle TJ, Hopkins RS. 2011. Low secondary transmission of 2009 pandemic influenza A (H1N1) in households following an outbreak at a summer camp: relationship to timing of exposure. Epidemiol Infect 139: 45-51. doi:10 .1017/S095026881000141X

Eshima N, Tokumaru O, Hara S, Bacal K, Korematsu S, Tabata M, Karukaya S, Yasui Y, Okabe N, Matsuishi T. 2011. Sex- and age-related differences in morbidity rates of 2009 pandemic influenza A H1N1 virus of swine origin in Japan. PLoS ONE 6: e19409. doi:10.1371/journal.pone .0019409

Esposito S, Molteni CG, Giliani S, Mazza C, Scala A, Tagliaferri L, Pelucchi C, Fossali E, Plebani A, Principi N. 2012. Toll-like receptor 3 gene polymorphisms and severity of pandemic A/H1N1/2009 influenza in otherwise healthy children. Virol J 9: 270. doi:10.1186/1743-422X-9-270

Everitt AR, Clare S, Pertel T, John SP, Wash RS, Smith SE, Chin CR, Feeley EM, Sims JS, Adams DJ, et al. 2012. IFITM3 restricts the morbidity and mortality associated with influenza. Nature 484: 519-523. doi:10.1038/na ture 10921

Feeley EM, Sims JS, John SP, Chin CR, Pertel T, Chen LM, Gaiha GD, Ryan BJ, Donis RO, Elledge SJ, et al. 2011. IFITM3 inhibits influenza A virus infection by preventing cytosolic entry. PLoS Pathog 7: e1002337. doi:10.1371/ journal.ppat.1002337

Ferguson FG, Wikby A, Maxson P, Olsson J, Johansson B. 1995. Immune parameters in a longitudinal study of a very old population of Swedish people: a comparison between survivors and nonsurvivors. J Gerontol A Biol Sci Med Sci 50A: B378-B382. doi:10.1093/gerona/50A.6 .B378

Fitch WM, Leiter JME, Li X, Palese P. 1991. Positive Darwinian evolution in human influenza A viruses. Proc Natl Acad Sci 88: 4270-4274. doi:10.1073/pnas.88.10.4270 
R.C. Mettelman and P.G. Thomas

Flannery B, Chung JR, Thaker SN, Monto AS, Martin ET, Belongia EA, McLean HQ, Gaglani M, Murthy K, Zimmerman RK, et al. 2017. Interim estimates of 2016-17 seasonal influenza vaccine effectiveness-United States, February 2017. Morb Mortal Wkly Rep 66: 167-171. doi:10.15585/mmwr.mm6606a3

Flannery B, Chung JR, Belongia EA, McLean HQ, Gaglani M, Murthy K, Zimmerman RK, Nowalk MP, Jackson ML Jackson LA, et al. 2018. Interim estimates of 2017-18 seasonal influenza vaccine effectiveness-United States, February 2018. Morb Mortal Wkly Rep 67: 180-185. doi:10.15585/mmwr.mm6706a2

Franceschi C, Bonafè M, Valensin S, Olivieri F, De Luca M, Ottaviani E, De Benedictis G. 2000. Inflamm-aging: an evolutionary perspective on immunosenescence. Ann NY Acad Sci 908: 244-254. doi:10.1111/j.1749-6632.2000 .tb06651.x

Francis T Jr. 1960. On the doctorine of orginal antigenic sin Proc Am Philos Soc 104: 572-578.

Frasca D, Riley RL, Blomberg BB. 2005. Humoral immune response and B-cell functions including immunoglobulin class switch are downregulated in aged mice and humans. Semin Immunol 17: 378-384. doi:10.1016/j.smim.2005 .05 .005

Furman D, Hejblum BP, Simon N, Jojic V, Dekker CL, Thiébaut R, Tibshirani RJ, Davis MM. 2014. Systems analysis of sex differences reveals an immunosuppressive role for testosterone in the response to influenza vaccination. Proc Natl Acad Sci 111: 869-874. doi:10.1073/pnas 1321060111

Furman D, Jojic V, Sharma S, Shen-Orr SS, Angel CJL, Onengut-Gumuscu S, Kidd BA, Maecker HT, Concannon P, Dekker CL, et al. 2015. Cytomegalovirus infection enhances the immune response to influenza. Sci Transl Med 7: 281ra43. doi:10.1126/scitranslmed.aaa2293

Gabriel G, Arck PC. 2014. Sex, immunity and influenza. J Infect Dis 209: S93-S99. doi:10.1093/infdis/jiu020

Gambotto A, Barratt-Boyes SM, de Jong MD, Neumann G, Kawaoka Y. 2008. Human infection with highly pathogenic H5N1 influenza virus. Lancet 371: 1464-1475. doi:10.1016/S0140-6736(08)60627-3

Garcia AM, Fadel SA, Cao S, Sarzotti M. 2000. T cell immunity in neonates. Immunol Res 22: 177-190. doi:10.1385/ IR:22:2-3:177

Gil A, Yassai MB, Naumov YN, Selin LK. 2015. Narrowing of human influenza A virus-specific T cell receptor $\alpha$ and $\beta$ repertoires with increasing age. J Virol 89: 4102-4116. doi:10.1128/JVI.03020-14

Gilbert M, Pfeiffer DU. 2012. Risk factor modelling of the spatio-temporal patterns of highly pathogenic avian influenza (HPAIV) H5N1: a review. Spat Spatiotemporal Epidemiol 3: 173-183. doi:10.1016/j.sste.2012.01.002

Ginaldi L, Loreto MF, Corsi MP, Modesti M, De Martinis M. 2001. Immunosenescence and infectious diseases. $\mathrm{Mi}$ crobes Infect 3: 851-857. doi:10.1016/S1286-4579(01) 01443-5

Glezen WP, Greenberg SB, Atmar RL, Piedra PA, Couch RB. 2000. Impact of respiratory virus infections on persons with chronic underlying conditions. J Am Med Assoc 283: 499-505. doi:10.1001/jama.283.4.499
Gounder AP, Boon ACM. 2019. Influenza pathogenesis: the effect of host factors on severity of disease. J Immunol 202: 341-350. doi:10.4049/jimmunol.1801010

Grant EJ, Quiñones-Parra SM, Clemens EB, Kedzierska K. 2016. Human influenza viruses and $\mathrm{CD}^{+} \mathrm{T}$ cell responses. Curr Opin Virol 16: 132-142. doi:10.1016/j.coviro 2016.01.016

Grohskopf LA, Alyanak E, Broder KR, Walter EB, Fry AM, Jernigan DB. 2019. Prevention and control of seasonal influenza with vaccines: recommendations of the advisory committee on immunization practices-United States, 2019-20 influenza season. MMWR Recomm Reports 68: 1-21. doi:10.15585/mmwr.rr6803al

Gubbels Bupp MR, Potluri T, Fink AL, Klein SL. 2018. The confluence of sex hormones and aging on immunity. Front Immunol 9: 1269. doi:10.3389/fimmu.2018.01269

Hackett S, Hill L, Patel J, Ratnaraja N, Ifeyinwa A, Farooqi M, Nusgen U, Debenham P, Gandhi D, Makwana N, et al. 2009. Clinical characteristics of paediatric H1N1 admissions in Birmingham, UK. Lancet 374: 605. doi:10.1016/ S0140-6736(09)61511-7

Hagan T, Cortese M, Rouphael N, Boudreau C, Linde C, Maddur MS, Das J, Wang H, Guthmiller J, Zheng NY, et al. 2019. Antibiotics-driven gut microbiome perturbation alters immunity to vaccines in humans. Cell 178: 1313-1328.e13. doi:10.1016/j.cell.2019.08.010

Harris KA, Freidl GS, Munoz OS, von Dobschuetz S, De Nardi M, Wieland B, Koopmans MPG, Stärk KDC, van Reeth K, Dauphin G, et al. 2017. Epidemiological risk factors for animal influenza A viruses overcoming species barriers. Ecohealth 14: 342-360. doi:10.1007/s10393017-1244-y

Hernandez N, Melki I, Jing H, Habib T, Huang SSY, Danielson J, Kula T, Drutman S, Belkaya S, Rattina V, et al. 2018. Life-threatening influenza pneumonitis in a child with inherited IRF9 deficiency. J Exp Med 215: 2567 2585. doi:10.1084/jem.20180628

Hoffmann J, Otte A, Thiele S, Lotter H, Shu Y, Gabriel G. 2015. Sex differences in H7N9 influenza A virus pathogenesis. Vaccine 33: 6949-6954. doi:10.1016/j.vaccine 2015.08.044

Horby P, Nguyen NY, Dunstan SJ, Kenneth Baillie J. 2013. An updated systematic review of the role of host genetics in susceptibility to influenza. Influenza Other Respi Viruses 7: 37-41. doi:10.1111/irv.12079

Huang QS, Bandaranayake D, Wood T, Newbern EC, Seeds R, Ralston J, Waite B, Bissielo A, Prasad N, Todd A, et al. 2019. Risk factors and attack rates of seasonal influenza infection: results of the southern hemisphere influenza and vaccine effectiveness research and surveillance (SHIVERS) Seroepidemiologic Cohort Study. J Infect Dis 219: 347-357. doi:10.1093/infdis/jiy443

Hulme KD, Gallo LA, Short KR. 2017. Influenza virus and glycemic variability in diabetes: a killer combination? Front Microbiol 8. doi:10.3389/fmicb.2017.00861

Imai M, Kawaoka Y. 2012. The role of receptor binding specificity in interspecies transmission of influenza viruses. Curr Opin Virol 2: 160-167. doi:10.1016/j.coviro.2012 .03 .003

Iuliano AD, Roguski KM, Chang HH, Muscatello DJ, Palekar R, Tempia S, Cohen C, Gran JM, Schanzer D, Cowling BJ, et al. 2018. Estimates of global seasonal influenza- 
associated respiratory mortality: a modelling study. Lancet 391: 1285-1300. doi:10.1016/S0140-6736(17)33293-2

Iwasaki A, Pillai PS. 2014. Innate immunity to influenza virus infection. Nat Rev Immunol 14: 315-328. doi:10 $1038 /$ nri3665

Jackson ML, Chung JR, Jackson LA, Phillips CH, Benoit J, Monto AS, Martin ET, Belongia EA, McLean HQ, Gaglani M, et al. 2017. Influenza vaccine effectiveness in the United States during the 2015-2016 season. N Engl J Med 377: 534-543. doi:10.1056/NEJMoa1700153

Khan N, Shariff N, Cobbold M, Bruton R, Ainsworth JA, Sinclair AJ, Nayak L, Moss PAH. 2002. Cytomegalovirus seropositivity drives the CD8 $\mathrm{T}$ cell repertoire toward greater clonality in healthy elderly individuals. J Immunol 169: 1984-1992. doi:10.4049/jimmunol.169.4.1984

Kim DD, Song WC. 2006. Membrane complement regulatory proteins. Clin Immunol 118: 127-136. doi:10.1016/j .clim.2005.10.014

Kim H, Webster RG, Webby RJ. 2018. Influenza virus: dealing with a drifting and shifting pathogen. Viral Immunol 31: 174-183. doi:10.1089/vim.2017.0141

Klein SL, Flanagan KL. 2016. Sex differences in immune responses. Nat Rev Immunol 16: 626-638. doi:10.1038/ nri.2016.90

Klein SL, Hodgson A, Robinson DP. 2012. Mechanisms of sex disparities in influenza pathogenesis. J Leukoc Biol 92: 67-73. doi:10.1189/jlb.0811427

Koelle K, Cobey S, Grenfell B, Pascual M. 2006. Epochal evolution shapes the phylodynamics of interpandemic influenza A (H3N2) in humans. Science 314: 18981903. doi:10.1126/science. 1132745

Koenig SM. 2001. Pulmonary complications of obesity. Am J Med Sci 321: 249-279. doi:10.1097/00000441200104000-00006

Krause JC, Tumpey TM, Huffman CJ, McGraw PA, Pearce MB, Tsibane T, Hai R, Basler CF, Crowe JE. 2010. Naturally occurring human monoclonal antibodies neutralize both 1918 and 2009 pandemic influenza A (H1N1) viruses. J Virol 84: 3127-3130. doi:10.1128/JVI.02184-09

Krementsov DN, Case LK, Dienz O, Raza A, Fang Q, Ather JL, Poynter ME, Boyson JE, Bunn JY, Teuscher C. 2017 Genetic variation in chromosome $\mathrm{Y}$ regulates susceptibility to influenza A virus infection. Proc Natl Acad Sci 114: 3491-3496. doi:10.1073/pnas.1620889114

Kunisaki KM, Janoff EN. 2009. Influenza in immunosuppressed populations: a review of infection frequency, morbidity, mortality, and vaccine responses. Lancet Infect Dis 9: 493-504. doi:10.1016/S1473-3099(09)70175-6

Le Saux S, Weyand CM, Goronzy JJ. 2012. Mechanisms of immunosenescence: lessons from models of accelerated immune aging. Ann NY Acad Sci 1247: 69-82. doi:10 $.1111 /$ j.1749-6632.2011.06297.x

Libster R, Bugna J, Coviello S, Hijano DR, Dunaiewsky M, Reynoso N, Cavalieri ML, Guglielmo MC, Areso MS Gilligan T, et al. 2010. Pediatric hospitalizations associated with 2009 pandemic influenza A (H1N1) in Argentina. N Engl J Med 362: 45-55. doi:10.1056/NEJMoa0907673

Lietz J, Westermann C, Nienhaus A, Schablon A. 2016. The occupational risk of influenza A (H1N1) infection among healthcare personnel during the 2009 pandemic: a systematic review and meta-analysis of observational studies.
PLoS ONE 11: e0162061. doi:10.1371/journal.pone .0162061

Lindau P, Mukherjee R, Gutschow MV, Vignali M, Warren EH, Riddell SR, Makar KW, Turtle CJ, Robins HS. 2019. Cytomegalovirus exposure in the elderly does not reduce CD8 T cell repertoire diversity. J Immunol 202: 476-483. doi:10.4049/jimmunol.1800217

Liu B, Havers F, Chen E, Yuan Z, Yuan H, Ou J, Shang M, Kang K, Liao K, Liu F, et al. 2014. Risk factors for influenza A(H7N9) disease-China, 2013. Clin Infect Dis 59: 787-794. doi:10.1093/cid/ciu423

Loth L, Gilbert M, Wu J, Czarnecki C, Hidayat M, Xiao X. 2011. Identifying risk factors of highly pathogenic avian influenza (H5N1 subtype) in Indonesia. Prev Vet Med 102: 50-58. doi:10.1016/j.prevetmed.2011.06.006

Louie JK, Acosta M, Winter K, Jean C, Gavali S, Schechter R, Vugia D, Harriman K, Matyas B, Glaser CA, et al. 2009. Factors associated with death or hospitalization due to pandemic 2009 influenza A(H1N1) infection in California. J Am Med Assoc 302: 1896-1902. doi:10.1001/jama .2009 .1583

Louie JK, Gavali S, Acosta M, Samuel MC, Winter K, Jean C, Glaser CA, Matyas BT, Schechter R, California Pandemic (H1N1) Working Group. 2010. Children hospitalized with 2009 novel influenza A(H1N1) in California. Arch Pediatr Adolesc Med 164: 1023. doi:10.1001/archpediat rics.2010.203

Louie JK, Acosta M, Samuel MC, Schechter R, Vugia DJ, Harriman K, Matyas BT. 2011. A novel risk factor for a novel virus: obesity and 2009 pandemic influenza A (H1N1). Clin Infect Dis 52: 301-312. doi:10.1093/cid/ ciq152

Mahamat A, Dussart P, Bouix A, Carvalho L, Eltges F, Matheus S, Miller MA, Quenel P, Viboud C. 2013. Climatic drivers of seasonal influenza epidemics in French Guiana, 2006-2010. J Infect 67: 141-147. doi:10.1016/j.jinf.2013 .03 .018

Maier HE, Lopez R, Sanchez N, Ng S, Gresh L, Ojeda S, Burger-Calderon R, Kuan G, Harris E, Balmaseda A, et al. 2018. Obesity increases the duration of influenza A virus shedding in adults. J Infect Dis 218: 1378-1382. doi:10.1093/infdis/jiy370

Maines TR, Jayaraman A, Belser JA, Wadford DA, Pappas C, Zeng H, Gustin KM, Pearce MB, Viswanathan K, Shriver $\mathrm{ZH}$, et al. 2009. Transmission and pathogenesis of swineorigin $2009 \mathrm{~A}(\mathrm{H} 1 \mathrm{~N} 1)$ influenza viruses in ferrets and mice. Science 325: 484-487. doi:10.1126/science.1177238

Makvandi-Nejad S, Laurenson-Schafer H, Wang LL, Wellington D, Zhao Y, Jin B, Qin L, Kite K, Moghadam HK, Song C, et al. 2018. Lack of truncated IFITM3 transcripts in cells homozygous for the rs12252-C variant that is associated with severe influenza infection. $J$ Infect Dis 217: 257-262. doi:10.1093/infdis/jix512

Marr LC, Tang JW, Van Mullekom J, Lakdawala SS. 2019. Mechanistic insights into the effect of humidity on airborne influenza virus survival, transmission and incidence. J R Soc Interface 16: 20180298. doi:10.1098/rsif .2018 .0298

Matrosovich MN, Matrosovich T, Gray T, Roberts NA, Klenk HD. 2004. Human and avian influenza viruses target different cell types in cultures of human airway epi- 
R.C. Mettelman and P.G. Thomas

thelium. Proc Natl Acad Sci 101: 4620-4624. doi:10.1073/ pnas.0308001101

McCullers JA. 2014. The co-pathogenesis of influenza viruses with bacteria in the lung. Nat Rev Microbiol 12: 252262. doi: $10.1038 /$ nrmicro3231

McDevitt J, Rudnick S, First M, Spengler J. 2010. Role of absolute humidity in the inactivation of influenza viruses on stainless steel surfaces at elevated temperatures. Appl Environ Microbiol 76: 3943-3947. doi:10.1128/AEM .02674-09

McElhaney JE, Effros RB. 2009. Immunosenescence: what does it mean to health outcomes in older adults? Curr Opin Immunol 21: 418-424. doi:10.1016/j.coi.2009.05 .023

McElhaney JE, Coler RN, Baldwin SL. 2013. Immunologic correlates of protection and potential role for adjuvants to improve influenza vaccines in older adults. Expert Rev Vaccines 12: 759-766. doi:10.1586/14760584.2013 .811193

McLean HQ, Thompson MG, Sundaram ME, Kieke BA, Gaglani M, Murthy K, Piedra PA, Zimmerman RK, Nowalk MP, Raviotta JM, et al. 2015. Influenza vaccine effectiveness in the United States during 2012-2013: variable protection by age and virus type. J Infect Dis 211: 15291540. doi:10.1093/infdis/jiu647

Medof ME, Kinoshita T, Nussenzweig V. 1984. Inhibition of complement activation on the surface of cells after incorporation of decay-accelerating factor (DAF) into their membranes. J Exp Med 160: 1558-1578. doi:10.1084/ jem.160.5.1558

Mehle A, Doudna JA. 2009. Adaptive strategies of the influenza virus polymerase for replication in humans. Proc Natl Acad Sci 106: 21312-21316. doi:10.1073/pnas .0911915106

Mertz D, Kim TH, Johnstone J, Lam PP, Science M, Kuster SP, Fadel SA, Tran D, Fernandez E, Bhatnagar N, et al 2013. Populations at risk for severe or complicated influenza illness: systematic review and meta-analysis. $B M$ J 347: f5061. doi:10.1136/bmj.f5061

Mertz D, Kim TH, Johnstone J, Lam PP, Science M, Kuster SP, Fadel SA, Tran D, Fernandez E, Bhatnagar N, et al. 2014. Populations at risk for severe or complicated avian influenza H5N1: a systematic review and meta-analysis. PLOS ONE 9: e89697. doi:10.1371/journal.pone.0089697

Meyer KC. 2001. The role of immunity in susceptibility to respiratory infection in the aging lung. Respir Physiol 128: 23-31. doi:10.1016/S0034-5687(01)00261-4

Monsalvo AC, Batalle JP, Lopez MF, Krause JC, Klemenc J, Hernandez JZ, Maskin B, Bugna J, Rubinstein C, Aguilar L, et al. 2011. Severe pandemic 2009 H1N1 influenza disease due to pathogenic immune complexes. Nat Med 17: 195-199. doi:10.1038/nm.2262

Monto AS, Petrie JG, Cross RT, Johnson E, Liu M, Zhong W, Levine M, Katz JM, Ohmit SE. 2015. Antibody to influenza virus neuraminidase: an independent correlate of protection. J Infect Dis 212: 1191-1199. doi:10.1093/in fdis/jiv195

Morens DM, Taubenberger JK, Fauci AS. 2008. Predominant role of bacterial pneumonia as a cause of death in pandemic influenza: implications for pandemic influenza preparedness. J Infect Dis 198: 962-970. doi:10.1086/ 591708
Morris DE, Cleary DW, Clarke SC. 2017. Secondary bacterial infections associated with influenza pandemics. Front Microbiol 8: 1041. doi:10.3389/fmicb.2017.01041

Moura FEA, Perdigão ACB, Siqueira MM. 2009. Seasonality of influenza in the tropics: a distinct pattern in northeastern Brazil. Am J Trop Med Hyg 81: 180-183. doi:10.4269/ ajtmh.2009.81.180

Mulcahy ME, McLoughlin RM. 2016. Staphylococcus aureus and influenza A virus: partners in coinfection. mBio 7: e02068-16. doi:10.1128/mBio.02068-16

Munoz FM. 2003. Influenza virus infection in infancy and early childhood. Paediatr Respir Rev 4: 99-104. doi:10 .1016/S1526-0542(03)00027-7

Murphy BR, Hinshaw VS, Sly DL, London WT, Hosier NT, Wood FT, Webster RG, Chanock RM. 1982. Virulence of avian influenza A viruses for squirrel monkeys. Infect Immun 37: 1119-1126.

Neidich SD, Green WD, Rebeles J, Karlsson EA, SchultzCherry S, Noah TL, Chakladar S, Hudgens MG, Weir SS, Beck MA. 2017. Increased risk of influenza among vaccinated adults who are obese. Int J Obes 41: 13241330. doi:10.1038/ijo.2017.131

Neumann G, Kawaoka Y. 2015. Transmission of influenza A viruses. Virology 479-480: 234-246. doi:10.1016/j.virol .2015 .03 .009

Ng S, Nachbagauer R, Balmaseda A, Stadlbauer D, Ojeda S, Patel M, Rajabhathor A, Lopez R, Guglia AF, Sanchez N, et al. 2019. Novel correlates of protection against pandemic H1N1 influenza A virus infection. Nat Med 25: 962967. doi:10.1038/s41591-019-0463-x

Nicholls JM, Chan MCW, Chan WY, Wong HK, Cheung CY, Kwong DLW, Wong MP, Chui WH, Poon LLM, Tsao SW, et al. 2007. Tropism of avian influenza A (H5N1) in the upper and lower respiratory tract. Nat Med 13: 147149. doi: $10.1038 / \mathrm{nm} 1529$

O’Brien KB, Morrison TE, Dundore DY, Heise MT, SchultzCherry S. 2011. A protective role for complement C3 protein during pandemic $2009 \mathrm{H} 1 \mathrm{~N} 1$ and H5N1 influenza A virus infection. PLoS ONE 6: e17377. doi:10.1371/ journal.pone. 0017377

Ohmit SE, Thompson MG, Petrie JG, Thaker SN, Jackson ML, Belongia EA, Zimmerman RK, Gaglani M, Lamerato L, Spencer SM, et al. 2014. Influenza vaccine effectiveness in the 2011-2012 season: protection against each circulating virus and the effect of prior vaccination on estimates. Clin Infect Dis 58: 319-327. doi:10.1093/cid/cit736

O’Riordan S, Barton M, Yau Y, Read SE, Allen U, Tran D. 2010. Risk factors and outcomes among children admitted to hospital with pandemic H1N1 influenza. CMAJ 182: 39-44. doi:10.1503/cmaj.091724

Oshansky CM, Gartland AJ, Wong SS, Jeevan T, Wang D, Roddam PL, Caniza MA, Hertz T, DeVincenzo JP, Webby RJ, et al. 2014. Mucosal immune responses predict clinical outcomes during influenza infection independently of age and viral load. Am J Respir Crit Care Med 189: 449462. doi:10.1164/rccm.201309-1616OC

Paich HA, Sheridan PA, Handy J, Karlsson EA, SchultzCherry S, Hudgens MG, Noah TL, Weir SS, Beck MA. 2013. Overweight and obese adult humans have a defective cellular immune response to pandemic H1N1 Influenza A virus. Obesity 21: 2377-2386. doi:10.1002/oby .20383 
Painter SD, Ovsyannikova IG, Poland GA. 2015. The weight of obesity on the human immune response to vaccination. Vaccine 33: 4422-4429. doi:10.1016/j.vaccine.2015.06 .101

Palmer DB. 2013. The effect of age on thymic function. Front Immunol 4: 316. doi:10.3389/fimmu.2013.00316

Papi A, Bellettato CM, Braccioni F, Romagnoli M, Casolari P, Caramori G, Fabbri LM, Johnston SL. 2006. Infections and airway inflammation in chronic obstructive pulmonary disease severe exacerbations. Am J Respir Crit Care Med 173: 1114-1121. doi:10.1164/rccm.200506-859OC

Pillai PS, Molony RD, Martinod K, Dong H, Pang IK, Tal MC, Solis AG, Bielecki P, Mohanty S, Trentalange M, et al. 2016. Mx1 reveals innate pathways to antiviral resistance and lethal influenza disease. Science 352: 463-466. doi:10.1126/science.aaf3926

Plessa E, Diakakis P, Gardelis J, Thirios A, Koletsi P, Falagas ME. 2010. Clinical features, risk factors, and complications among pediatric patients with pandemic influenza A (H1N1). Clin Pediatr (Phila) 49: 777-781. doi:10.1177/ 0009922810368558

Poirier P, Alpert MA, Fleisher LA, Thompson PD, Sugerman HJ, Burke LE, Marceau P, Franklin BA. 2009. Cardiovascular evaluation and management of severely obese patients undergoing surgery: a science advisory from the American Heart Association. Circulation 120: 86-95. doi:10.1161/CIRCULATIONAHA.109.192575

Potter CW, Schild GC. 1967. The incidence of HI antibody to Influenza virus A2/Singapore/ 1/57 in individuals of blood groups A and O. J Immunol 98: 1320-1325.

Prakash S, Agrawal S, Cao J, Gupta S, Agrawal A. 2013. Impaired secretion of interferons by dendritic cells from aged subjects to influenza: role of histone modifications. Age (Dordr) 35: 1785-1797. doi:10.1007/s11357-0129477-8

Rajão DS, Pérez DR. 2018. Universal vaccines and vaccine platforms to protect against influenza viruses in humans and agriculture. Front Microbiol 9: 123. doi:10.3389/ fmicb.2018.00123

Ramos I, Krammer F, Hai R, Aguilera D, Bernal-Rubio D, Steel J, García-Sastre A, Fernandez-Sesma A. 2013. H7N9 influenza viruses interact preferentially with $\alpha 2,3$-linked sialic acids and bind weakly to $\alpha 2,6$-linked sialic acids. $J$ Gen Virol 94: 2417-2424. doi:10.1099/vir.0.056184-0

Rhim JW, Go EJ, Lee KY, Youn YS, Kim MS, Park SH, Kim JC, Kang JH. 2012. Pandemic 2009 H1N1 virus infection in children and adults: a cohort study at a single hospital throughout the epidemic. Int Arch Med 5: 13. doi:10 $.1186 / 1755-7682-5-13$

Robinson DP, Lorenzo ME, Jian W, Klein SL. 2011. Elevated $17 \beta$-estradiol protects females from influenza A virus pathogenesis by suppressing inflammatory responses. PLoS Pathog 7: e1002149. doi:10.1371/journal.ppat .1002149

Rogo LD, Rezaei F, Marashi SM, Yekaninejad MS, Naseri M, Ghavami N, Mokhtari-Azad T. 2016. Seasonal influenza $\mathrm{A} / \mathrm{H} 3 \mathrm{~N} 2$ virus infection and IL-1 $\beta$, IL-10, IL-17, and IL28 polymorphisms in Iranian population. J Med Virol 88: 2078-2084. doi:10.1002/jmv.24572

Root ED, Agustian D, Kartasasmita C, Uyeki TM, Simões EAF. 2017. Demographic and ecological risk factors for human influenza A virus infections in rural Indonesia.
Influenza Other Respi Viruses 11: 425-433. doi:10.1111/ irv. 12468

Russell CJ, Hu M, Okda FA. 2018. Influenza hemagglutinin protein stability, activation, and pandemic risk. Trends Microbiol 26: 841-853. doi:10.1016/j.tim.2018.03.005

Shaman J, Kohn M. 2009. Absolute humidity modulates influenza survival, transmission, and seasonality. Proc Natl Acad Sci 106: 3243-3248. doi:10.1073/pnas .0806852106

Shaman J, Pitzer VE, Viboud C, Grenfell BT, Lipsitch M. 2010. Absolute humidity and the seasonal onset of influenza in the continental United States. PLoS Biol 8: e1000316. doi:10.1371/journal.pbio.1000316

Shaw AC, Goldstein DR, Montgomery RR. 2013. Agedependent dysregulation of innate immunity. Nat Rev Immunol 13: 875-887. doi:10.1038/nri3547

Sheridan PA, Paich HA, Handy J, Karlsson EA, Hudgens MG, Sammon AB, Holland LA, Weir S, Noah TL, Beck MA. 2012. Obesity is associated with impaired immune response to influenza vaccination in humans. Int J Obes 36: 1072-1077. doi:10.1038/ijo.2011.208

Sheth AN, Althoff KN, Brooks JT. 2011. Influenza susceptibility, severity, and shedding in HIV-infected adults: a review of the literature. Clin Infect Dis 52: 219-227. doi:10 $.1093 / \mathrm{cid} / \mathrm{ciq} 110$

Siston AM, Rasmussen SA, Honein MA, Fry AM, Seib K, Callaghan WM, Louie J, Doyle TJ, Crockett M, Lynfield R, et al. 2010. Pandemic 2009 influenza A(H1N1) virus illness among pregnant women in the United States. J Am Med Assoc 303: 1517-1525. doi:10.1001/jama.2010.479

Skehel JJ, Wiley DC. 2000. Receptor binding and membrane fusion in virus entry: the influenza hemagglutinin. Annu Rev Biochem 69: 531-569. doi:10.1146/annurev.biochem .69.1.531

Smith AM, McCullers JA. 2014. Secondary bacterial infections in influenza virus infection pathogenesis. Curr Top Microbiol Immunol 385: 327-356.

Solana R, Tarazona R, Gayoso I, Lesur O, Dupuis G, Fulop T. 2012. Innate immunosenescence: effect of aging on cells and receptors of the innate immune system in humans. Semin Immunol 24: 331-341. doi:10.1016/j.smim.2012 .04 .008

Sridhar S, Begom S, Bermingham A, Hoschler K, Adamson W, Carman W, Bean T, Barclay W, Deeks JJ, Lalvani A. 2013. Cellular immune correlates of protection against symptomatic pandemic influenza. Nat Med 19: 13051312. doi: $10.1038 / \mathrm{nm} .3350$

Sridhar S, Begom S, Hoschler K, Bermingham A, Adamson W, Carman W, Riley S, Lalvani A. 2015. Longevity and determinants of protective humoral immunity after pandemic influenza infection. Am J Respir Crit Care Med 191: 325-332. doi:10.1164/rccm.201410-1798OC

Sridharan A, Esposo M, Kaushal K, Tay J, Osann K, Agrawal S, Gupta S, Agrawal A. 2011. Age-associated impaired plasmacytoid dendritic cell functions lead to decreased CD4 and CD8 T cell immunity. Age (Dordr) 33: 363376. doi:10.1007/s11357-010-9191-3

Steinhauer DA, Domingo E, Holland JJ. 1992. Lack of evidence for proofreading mechanisms associated with an RNA virus polymerase. Gene 122: 281-288. doi:10.1016/ 0378-1119(92)90216-C 
Stevens J, Blixt O, Glaser L, Taubenberger JK, Palese P, Paulson JC, Wilson IA. 2006. Glycan microarray analysis of the hemagglutinins from modern and pandemic influenza viruses reveals different receptor specificities. J Mol Biol 355: 1143-1155. doi:10.1016/j.jmb.2005.11.002

Tamerius JD, Shaman J, Alonso WJ, Bloom-Feshbach K, Uejio CK, Comrie A, Viboud C. 2013. Environmental predictors of seasonal influenza epidemics across temperate and tropical climates. PLoS Pathog 9: e1003194. doi:10 .1371/journal.ppat.1003194

Tashiro M, Ciborowski P, Klenk HD, Pulverer G, Rott R 1987. Role of Staphylococcus protease in the development of influenza pneumonia. Nature 325: 536-537. doi:10 $.1038 / 325536 \mathrm{a} 0$

Taubenberger JK, Kash JC. 2010. Influenza virus evolution, host adaptation, and pandemic formation. Cell Host Microbe 7: 440-451. doi:10.1016/j.chom.2010.05.009

Taubenberger JK, Morens DM. 2006. 1918 influenza: the mother of all pandemics. Emerg Infect Dis 12: 15-22. doi:10.3201/eid1209.05-0979

Taubenberger JK, Reid AH, Janczewski TA, Fanning TG. 2001. Integrating historical, clinical and molecular genetic data in order to explain the origin and virulence of the 1918 Spanish influenza virus. Philos Trans R Soc B Biol Sci 356: 1829-1839. doi:10.1098/rstb.2001.1020

Tellier R. 2006. Review of aerosol transmission of influenza A virus. Emerg Infect Dis 12: 1657-1662. doi:10.3201/ eid1211.060426

Thompson WW, Shay DK, Weintraub E, Brammer L, Cox N, Anderson LJ, Fukuda K. 2003. Mortality associated with influenza and respiratory syncytial virus in the United States. J Am Med Assoc 289: 179. doi:10.1001/jama.289 .2 .179

Thors V, Christensen H, Morales-Aza B, Vipond I, Muir P, Finn A. 2016. The effects of live attenuated influenza vaccine on nasopharyngeal bacteria in healthy 2 to 4 year olds: a randomized controlled trial. Am J Respir Crit Care Med 193: 1401-1409. doi:10.1164/rccm.201510-2000OC

Toapanta FR, Ross TM. 2009. Impaired immune responses in the lungs of aged mice following influenza infection. Respir Res 10: 112. doi:10.1186/1465-9921-10-112

Vaillant L, La Ruche G, Tarantola A, Barboza P, for the epidemic intelligence team at InVS1. 2009. Epidemiology of fatal cases associated with pandemic H1N1 influenza 2009. Eurosurveillance 14: 19309. doi:10.2807/ese.14.33 .19309-en

Watkin IJ, Tills D, Heath RB. 1975. Studies of the genetic susceptibility of individuals to infection with influenza viruses. Humangenetik 30: 75-79. doi:10.1007/ BF00273634
Webby RJ, Webster RG. 2001. Emergence of influenza A viruses. Philos Trans $R$ Soc B Biol Sci 356: 1817-1828. doi:10.1098/rstb.2001.0997

Webster RG, Laver WG. 1972. The origin of pandemic influenza. Bull World Health Organ 47: 449-452.

Webster RG, Laver WG, Air GM, Schild GC. 1982. Molecular mechanisms of variation in influenza viruses. Nature 296: 115-121. doi:10.1038/296115a0

WHO. 2010. Sex, gender and influenza, pp. 1-62. WHO Press, Geneva.

WHO. 2013. Global epidemiological surveillance standards for influenza. WHO Press, Geneva.

Wilking H, Buda S, Von Der Lippe E, Altmann D, Krause G, Eckmanns T, Haas W. 2010. Mortality of 2009 pandemic influenza A (H1N1) in Germany. Eurosurveillance 15: 5. doi:10.2807/ese.15.49.19741-en

Wong SS, Oshansky CM, Guo XZJ, Ralston J, Wood T, Seeds R, Newbern C, Waite B, Reynolds G, Widdowson MA, et al. 2018. Severe influenza is characterized by prolonged immune activation: results from the SHIVERS Cohort Study. J Infect Dis 217: 245-256. doi:10.1093/infdis/ jix571

Yan J, Grantham M, Pantelic J, De Mesquita PJB, Albert B, Liu F, Ehrman S, Milton DK. 2018. Infectious virus in exhaled breath of symptomatic seasonal influenza cases from a college community. Proc Natl Acad Sci 115: 10811086. doi:10.1073/pnas.1716561115

Zhang YH, Zhao Y, Li N, Peng YC, Giannoulatou E, Jin RH, Yan HP, Wu H, Liu JH, Liu N, et al. 2013. Interferoninduced transmembrane protein-3 genetic variant rs12252-C is associated with severe influenza in Chinese individuals. Nat Commun 4: 1418. doi:10.1038/ ncomms 2433

Zhou J, To KKW, Dong H, Cheng ZS, Lau CCY, Poon VKM, Fan YH, Song YQ, Tse H, Chan KH, et al. 2012. A functional variation in CD55 increases the severity of 2009 pandemic H1N1 influenza A virus infection. J Infect Dis 206: 495-503. doi:10.1093/infdis/jis378

Zimmerman RK, Nowalk MP, Chung J, Jackson ML, Jackson LA, Petrie JG, Monto AS, McLean HQ, Belongia EA, Gaglani M, et al. 2016. 2014-2015 influenza vaccine effectiveness in the United States by vaccine type. Clin Infect Dis 63: 1564-1573. doi:10.1093/ cid/ciw635

Zitzow LA, Rowe T, Morken T, Shieh W-J, Zaki S, Katz JM. 2002. Pathogenesis of avian influenza A (H5N1) viruses in ferrets. J Virol 76: 4420-4429. doi:10.1128/JVI.76.9 $.4420-4429.2002$ 


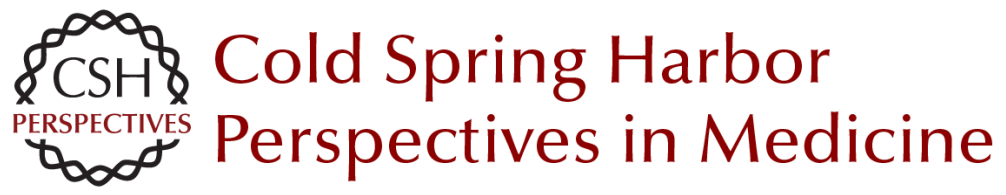

\section{Human Susceptibility to Influenza Infection and Severe Disease}

Robert C. Mettelman and Paul G. Thomas

Cold Spring Harb Perspect Med 2021; doi: 10.1101/cshperspect.a038711 originally published online January 21,2020

\section{Subject Collection Influenza: The Cutting Edge}

\section{Emerging HxNy Influenza A Viruses} William J. Liu, Yan Wu, Yuhai Bi, et al.

Equine Influenza

Thomas M. Chambers

\section{Human Influenza Epidemiology \\ Sukhyun Ryu and Benjamin J. Cowling}

Host Cell Factors That Interact with Influenza

Virus Ribonucleoproteins

Ecco Staller and Wendy S. Barclay

Induction and Evasion of Type-I Interferon

Responses during Influenza A Virus Infection

Raquel Muñoz-Moreno, Carles Martínez-Romero and Adolfo García-Sastre

Structure and Function of Influenza Polymerase Joanna M. Wandzik, Tomas Kouba and Stephen Cusack

H7N9 Influenza Virus in China Chengjun Li and Hualan Chen

H5 Influenza Viruses in Egypt Rabeh El-Shesheny, Ahmed Kandeil, Ahmed Mostafa, et al.
Antivirals Targeting the Neuraminidase Larisa Gubareva and Teena Mohan

Accessory Gene Products of Influenza A Virus Rute M. Pinto, Samantha Lycett, Eleanor Gaunt, et al.

Influenza Immunization in the Context of

Preexisting Immunity Susanne L. Linderman, Ali H. Ellebedy, Carl Davis, et al.

Hemagglutinin Structure and Activities Steven J. Gamblin, Sébastien G. Vachieri, Xiaoli Xiong, et al.

Live Attenuated Cold-Adapted Influenza Vaccines Kanta Subbarao

Next-Generation Influenza Vaccines Masaru Kanekiyo and Barney S. Graham

Selective Genome Packaging Mechanisms of Influenza A Viruses Takeshi Noda

Systems Biological Analysis of Immune Response to Influenza Vaccination Mario Cortese, Amy C. Sherman, Nadine G. Rouphael, et al.

For additional articles in this collection, see http://perspectivesinmedicine.cshlp.org/cgi/collection/ 